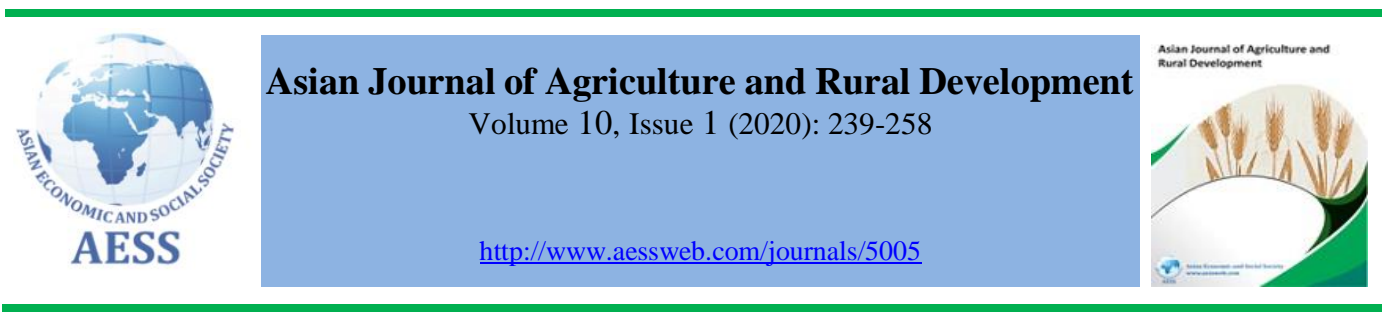

\title{
HUNGER PROJECT CREDIT FACILITY AND MAIZE PRODUCTIVITY IN GHANA
}

Isaac Tweneboah a Department of Agriculture, Kwahu West Municipality, Nkawkaw, Ghana Asante $^{\mathrm{a}} \quad{ }^{\mathrm{b}}$ Department of Banking and Finance, University of Professional Studies, Accra Ghana

Raymond K.

${ }^{c}$ Department of Agricultural Economics, Agribusiness and Extension, of

Dziwornu $^{\text {b }}$

Agriculture, College of Agriculture and Natural Resources, Kwame Nkrumah

Dadson Awunyo-

Vitor $^{c}$

University of Science and Technology, Ghana

$\checkmark$ tweneasante@yahoo.com (Corresponding author)

\section{ARTICLE HISTORY: \\ Received: 04-Feb-2020 \\ Accepted: 20-Apr-2020 \\ Online Available: 14-May- 2020}

\section{Keywords:}

Credit,

Maize productivity,

Hunger project,

Endogenous switching

regression model,

Ghana

\begin{abstract}
This paper evaluated the effect of credit facility on the productivity of participants of the Hunger Project in Ghana. Primary data was collected from randomly sampled 170 beneficiary and non-beneficiary smallholder maize farmers of the project in the Kwahu West Municipality. Descriptive statistics and the endogenous switching regression model were used to analyse the data. The results showed that gender, number of livestock owned by the farmer, previous year's maize income, farmers' perception of lending procedures of the Project and farmers' perception of the distance between residence and the epicenter (loan center) were the factors influencing farmers' decision to take part in the Hunger Project credit programme. The study also revealed that farmers who benefited from the programme had a significant increase in maize output: thus, the credit facility significantly influenced farm productivity. In addition to maize farming, farmers should be encouraged to keep livestock, and the project management should open loan centres close to the farmers to improve access to loan by the farmers, particularly current nonbeneficiaries, to improve their productivity. This should be supported by an extension of education and training.
\end{abstract}

\section{Contribution/ Originality}

Farmers' participation in agricultural credit programme such as the Hunger Project is essential for its impact evaluation. The study found that agriculture credit programme specific factors significantly influence small scale maize farmers' participation decision. Also, the increase in the productivity of participants resolves credit-productivity puzzle.

DOI: 10.18488/journal.1005/2020.10.1/1005.1.239.258

ISSN (P): 2304-1455/ISSN (E):2224-4433

How to cite: Isaac Tweneboah Asante, Raymond K. Dziwornu and Dadson Awunyo-Vitor (2020). Hunger Project credit facility and maize productivity in Ghana. Asian Journal of Agriculture and Rural Development, 10(1), 239-258.

(C) 2020 Asian Economic and Social Society. All rights reserved. 


\section{INTRODUCTION}

Maize is one of the staple crops in Ghana, and it accounts for more than half of the total cereal production in the country. Maize plays a key role in contributing to food security in Ghana (Armah, 2009). According to Awunyo-Vitor et al. (2014), maize yield averages about 1.7 tons per hectare (tons/ha) in Ghana. However, Edgerton (2009) noted that in developed countries the average yield of maize is $4.9 \mathrm{t} / \mathrm{ha}$, although, from a scientific experiment, a yield of $6.0 \mathrm{t} / \mathrm{ha}$ is achievable (MOFA, 2011). Thus, the productivity of maize farmers in Ghana is therefore low. The dawdling productivity growth in maize production is attributed to farmers' access to improved seed, fertilizer and adoption of improved agronomic and farm management practices (Ragasa et al., 2013). Increasing maize productivity can boost food accessibility as well as rural incomes: thus access to extension education, loan facilities for resource-constrained farmers have dominated the focus of researchers, policymakers and other development partners.

Maize is an important staple crop enjoyed across the country and in many households: virtually every dish in the Ghanaian cuisine uses maize. Its meal is made into porridge, kenkey (Fanti or Ga), banku, tuozaafi, abolo, kooko and tom brown. For industrial use, maize is sometimes used as a starch source for the brewing industry. The livestock feed industries also depend on maize to prepare feed for poultry and other livestock. Ragasa et al. (2013) posit that about 13 percent of maize produced in the country is used for animal poultry feed. The demand for maize for feed production in the poultry sector is estimated to grow by 10 percent per annum (Hurelbrink and Boohene, 2011). The importance of maize to the economy and as a food security crop cannot be over-emphasized. There is, therefore, the need to initiate agricultural development projects or programmes that aims at enhancing maize productivity. This will not only lead to increased food availability but also results in an improved standard of living of the populace.

There is an increasing demand for maize for human consumption and animal feed in the country due to industrialization and urbanization (Andam et al., 2015; 2017). This requires measures to raise the productivity of maize per hectare. This could be achieved through the use of various policies, programmes and projects such as the adoption of improved technologies (improved maize seeds, agrochemicals including fertilizer), use of tractors, irrigation schemes, provision of credit etc. geared towards an increase in maize productivity growth.

The Government of Ghana, in an attempt to enhance agricultural productivity in general and maize in particular, introduced four main initiatives to support farmers. These initiatives include subsidy on fertilizer, mechanization services and support for block farming. These interventions have similar features like other initiatives of the government that were abandoned shortly after they were introduced in the past (Benin et al., 2013). The block farms and marketing programme have been abandoned, the fertilizer subsidy was not always readily available, and when available smallholder farmers cannot afford to purchase it: thus affecting the production of maize.

The Hunger Project (THP)-Ghana is a non-governmental organization with its headquarters based in New York, USA. It currently operates in Africa, Asia and Latin America. It started its operations in Ghana in 1996 and currently operates in five regions namely; Eastern, Ashanti, Greater Accra, Volta and Central Regions (The Hunger Project Ghana, 2013). It scaled up its operation to the Eastern Region in 2006. The Hunger Project covers all metropolitan, municipal and district assemblies (MMDAs) in the country, except for the New Juabeng Municipality. It currently runs thirty-eight loan centres in the Eastern Region.

The underlying aim of such an enterprise is to reduce hunger and poverty by enhancing the productivity of smallholder farmers. The food security and agricultural development component of THP seeks to achieve this objective which is one of the Millennium Development Goals (MDGs) through several interventions targeting farmers in rural communities. They include the provision of 
input credit such as improved seed, fertilizer, agrochemicals and financial credit. Enhancing the productivity of smallholder farmers through increased access to farm input and credit has great implications for food security and household income enhancement.

Food insecurity and poverty remains a predominant problem in Ghana, particularly among smallscale farmers in rural communities where agriculture is generally central to their livelihood. The seventh round of the Ghana Living Standard Survey (GLSS7) conducted in 2016/2017 estimated poverty headcount in Ghana as 23.4 percent. It is also estimated that about forty-three percent of the poor in Ghana are into agriculture and live in rural areas (GLSS, 2018). To bring farming communities out of hunger and poverty, the Hunger Project-Ghana has been supporting maize farmers with agricultural inputs and loans to reduce hunger and poverty through enhancing agricultural productivity. A preliminary study before the introduction of the credit programme indicated that maize farmers were producing far below the optimum yield of $2.0 \mathrm{t} / \mathrm{ha}$ due to lack of credit facilities, access to fertilizer and other agro-inputs as well as frequent access to information on improved farming methods (THPG, 2013). The Hunger Project, therefore, came in to supply solutions to the challenges that contribute to low productivity.

The Hunger Project programme is however saddled with high default in the repayment of the credit facilities (The Hunger Project Ghana, 2013), and also most farmers have not taken advantage of the credit programme as expected to maximize their production. This raises the question of whether the credit received by the farmers does not result in improved productivity. It has been argued that agricultural credit increases access to production input, technology and improves the allocative efficiency of farmers, which ultimately leads to enhance productivity (Awunyo-Vitor et al., 2016 and Dong et al., 2012). However, other findings have revealed a negative relationship between credit and productivity (Boucher and Guirkinger, 2007). It is important to solve the puzzle as to whether The Hunger Project Credit improves productivity or not. The aim of the study is therefore to conduct an ex-pose evaluation of the financial credit intervention by the Hunger Project to ascertain its effect on maize productivity in Ghana.

\section{LITERATURE REVIEW}

\subsection{Factors influencing agricultural programme participation}

According to Cole (2006), farmers do not participate in agricultural programmes because they lack knowledge about the programme and confidence in themselves. The author was also of the view that lack of time and interest on the part of farmers affect their participation in agricultural intervention programmes. Ghimir et al. (2009) stressed that the farmer's lack of confidence in such programmes as a result of inadequate education on the programme affects their participation. Also, most farmers do not participate in agricultural programmes because the intention of most programmes is not made clear to them. They further argued that the lack of interest of farmers to participate is mostly due to the failure of previous programme interventions.

Lack of resource constraints on participation is highlighted by Ajayi (2005) who noted that lack of access to productive resources such as land, credit, farm inputs, sufficient extension services and suitable technology are the limiting factors for women's participation in food production and food security programmes globally. Aref (2010) also asserted that weak government institutions; poor human resource development and reliance on government in rural communities hinder agricultural programme participation. Ghimir et al. (2009) argued that for farmers to decide to participate in a programme or decline participation in a programme is influenced by the way information about the programme was conveyed to them.

Nxumalo and Oladele (2013) opined that lack of or inadequate access to resources such as farmland, credit facilities were major factors that influence individual decision to participate in a programme. They claim that age, gender and income are factors that influence participation. 
Farmers' participation is also influenced by educational level and training acquired. Other variables that influence farmers programme participation decision include farm income, size of land available for cropping (Ganesh and Surendra, 2005). Oladele (2012) also emphasises that farmers participation in such programmes is influenced by age and education level.

Telayneh (2010) noted that agricultural programme participation is influenced by a broad group of factors; namely institutional, socio-economic, and structural. Institutional factors include inappropriateness to the needs of farmers; the distance of training centre; and lack of facilities and incompetent facilitators. Socio-cultural factors are farmers' unawareness and low expectations, and structural factors include a central planning system and weak local institutional capacity.

Alam et al. (2012) also observed that individual satisfaction level, household size, available family labour, farm income and educational level of farmers influence programme participation. According to Botlhoko and Oladele (2013), the household size of the farmer plays a significant role in the participation of agricultural projects. Sithole et al. (2014) in their study also found the age of farmer, access to credit, distance to the programme office, farm size, and membership of farmerbased organisation as factors influencing farmers' participation in an agricultural programme.

\subsection{Credit access and agricultural productivity}

According to Ozowa (2007) "Agricultural credit is defined as all loans and advances granted to borrowers to finance and service production activities relating to agriculture, fisheries, forestry and also for processing, marketing, storage and distribution of products resulting from these activities". Adegeye and Dittoh (1985) in their study operationalized credit as "the process of obtaining control over the use of money, goods and services in exchange for a promise to repay at a future date". In this study, credit refers to only financial credit, that is, the amount of money (funds in cash) given to farmers to support their farming activities. Several factors were found to theoretically influence farmers' access to the loan. Yehuala (2008) classified these factors into demographic factors; socioeconomic factors; institutional factors; and communication factors.

In agricultural production, the amount of output that is produced by a given amount of input is referred to as agricultural productivity. Agricultural productivity is therefore defined as "the ratio of total farm outputs to total inputs used in agricultural production" (Mundlak, 1992). To increase output, there is a need to increase the amount of input used as well as the quality of the input and must be used at the appropriate time. These inputs include high yield varieties, agrochemicals such as fertilizers herbicides and pesticides as well as irrigation facilities in areas where rainfall is inadequate. Resource-poor farmers in sub-Saharan Africa (SSA) lack access to agricultural credit thus cannot afford the aforementioned improved technologies, which have the potential to drive agricultural productivity. To alleviate poverty, it is imperative to improve the productivity of farmers, particularly those living in rural areas and cultivate less than 1 hactare.

According to Hussien and Perera (2004), several factors and services influence crop productivity. These factors are access to farmland, suitable climatic conditions, appropriate agronomic and farm management practices as well as individual and institutional factors. The role of farmer support services cannot be overemphasised because they are essential for the productivity improvement of small-scale farmers. Empirical evidence in the literature shows that extending support services to resource-poor farmers has implications on rural household welfare.

Boucher and Guirkinger (2007) used the endogenous switching regression model to examine the effect of lack of access to credit on small-scale farmers' productivity in Peru. The authors employed panel data for which they controlled for selection bias problem and unobserved heterogeneity. Their results revealed that relaxing formal credit constraints of farmers would increase their productivity by more than a quarter. 
According to Muturi and Nzomo (2014), farmer's income can be enhanced with access to credit from agricultural credit programmes. Relaxing credit constraint of farmers helps to improve their productivity via economics of scale and efficiency in the use of other available resources. Ciaian et al. (2011) concluded in their study that enhancing credit access to farmers increases variable input use by $2.3 \%$ and capital investment up by $29 \%$. They also found out that increase access to loan increases total factor productivity by $1.9 \%$. The results suggest that improving credit access result in input intensification on farms. Butler and Cornaggia (2011) studied the relationship between credit access and farm productivity using a triple differences testing methodology. Their result revealed that access to finance tends to increase the productivity of farmers.

Based on the literature reviewed, it is anticipated that maize farmers' access to programme credit will increase access and improve farm input use and consequently increase farm productivity.

\section{METHODOLOGY}

\subsection{Sample size and sampling technique}

The study was conducted in the Kwahu West Municipality, located in the Eastern Region of Ghana. The Municipality is predominantly agriculture, with maize being one of the major crops. The crop sub-sector employs 97.5 percent of the labour force of the agriculture sector in the Municipality. Also, 61 percent of households in the Municipality are poor (KWMA, 2014). It is estimated that only $9 \%$ of maize farmers within the municipality have access to formal credit facility (The Hunger Project Ghana, 2013). In line with this, Bartlett et al. (2001) formula was used to estimate the sample size for the study. The formula is specified as:

$$
n=\frac{s^{2}(x)(y)}{E^{2}}
$$

Where $n$ represent the sample size to use, $x$ is the fraction of the population of maize farmers who participated in the programme (accessed credit) and $y$ is the fraction of maize farmers who did not participate (not access credit), $S$ is the number of standard deviation for $95 \%$ confidence interval, and $E$ is $5 \%$ margin of error allowed for the study.

Based the above, the sample size was calculated as follows:

$$
\mathrm{n}=\frac{1.96^{2}(0.09)(0.91)}{0.05^{2}}=126
$$

The sample size $(n)$ is equal to 126 . The project operates in 17 communities, hence to capture the adequate number of respondents from these communities; the sample size was increased by $35 \%$. The total sample was then proportionally distributed between the Hunger Project beneficiaries (participants) and non-beneficiaries (non-participants) in the study area.

A multi-stage sampling technique was employed in selecting the respondents. At the first stage of the selection, 17 communities where The Hunger Project is operational were purposively sampled. Stratified sampling technique was employed at the second stage of the sampling process to group maize farmers into beneficiaries and non-beneficiaries. In the third stage, the respondents were selected randomly from each stratum. In all 85 beneficiary and 85 non-beneficiary smallholder maize farmers were selected. A well-structured questionnaire was used to collect data and information from the sampled respondents.

\subsection{Analytical framework}

The Hunger Project is a non-governmental organization that seeks to increase maize farmers' productivity through credit intervention. The credit package includes the provision of cash and non- 
cash credit. The non-cash credit comes in the form of improved seed, fertilizer and herbicide. To achieve the objective of study two econometric challenges arise; these are self-selection bias and endogeneity. Self-selection bias arises as a result of non-random selection of farmers into the programme. Based on the programme participation process, farmers need self-select (apply) to participate in the programme. Therefore, participation decision (access credit) for the programme is based on their expectation, objectives and unobservable characteristic. Endogeneity problem may also arise if the farmer's characteristics, which are not observed such as, experience in farming, influence farmer's decision to make use of an intervention (credit programme) and the outcome variable (productivity). The endogeneity problem may lead to an inconsistent estimate of the result if unobservable characteristics of farmers are not accounted for.

According to Feder et al. (1990) analytical approaches that pooled sample observation together in estimating a production function which comprises credit as an independent variable in credit supply equation and other approaches that estimate separate production functions and then proceed to compare the result are flawed. This is because credit beneficiaries and non-beneficiaries are not always homogenous and beneficiaries for whom credit constraint is not binding may have zero marginal effect of credit on their productivity. Finally, they argued that the supply function may differ with regards to variables and parameters, depending on whether liquidity is a binding constraint. Dong et al. (2012) and Nuryartono (2005) proposed that the most suitable econometric approach is to adopt a two-stage regression model such as the endogenous switching regression model.

At the first stage probit/logit model may be used to identify factors which influence the farmer's decision to participate (access to credit) in The Hunger Project credit programme. The logit and probit are binary models that overcome the limitations of the Linear Probability Model (LPM) by using a function that transforms the regression model that fits values that are bounded within 0 and 1 (Gujarati, 2004). The probit model resolves the problem of heteroscedasticity (Asante et al., 2011) and has a believable error term distribution and realistic probabilities (Nagler 1994). The probit model assumes a standard normal distribution. According to Long (1997), the choice between logit and probit models is largely one of convenience and convention, since the essential results are generally indistinguishable. The choice between the logit and probit models is, therefore, the decision of the researcher. Studies that have applied the probit model to analyze farmers' credit participation decision include Asante et al. (2017), Nxumalo and Oladele (2013), and Shete and Garcia (2011).

In this study, the probit model was used and the participation (access to credit) equation is given as:

$$
\mathrm{Z}_{\mathrm{i}}^{*}=\mathrm{X} \gamma+\mu, \mu \sim \mathrm{N}(0,1)
$$

Where the dependent variable $Z$ denote participation (credit access) which is specified as one (1) if the farmer participates (access credit) from The Hunger Project credit programme and zero otherwise (non- participant in The Hunger Project credit programme), $X$ is a set of exogenous variables influencing farmers' participation or non-participation in The Hunger Project; $\mu$ is the error term. The participation status of the farmers can be specified as follows:

$$
\begin{array}{r}
Z_{i}=1 \text { if } X \gamma \geq \mu \\
Z_{i}=0 \text { if } X \gamma<\mu
\end{array}
$$

The productivity equation for participant and non-participants in The Hunger Project credit programme can be specified as follows:

$$
\mathrm{Y}_{1 \mathrm{i}}=\beta_{1} \mathrm{X}_{1 \mathrm{i}}+\varepsilon_{1 \mathrm{i}} \quad \text { if } \mathrm{Z}_{\mathrm{i}}=1
$$




$$
Y_{2 i}=\beta_{2} X_{2 i}+\varepsilon_{2 i} \quad \text { if } Z_{i}=0
$$

Where $Y_{i}$ is the dependent variable (maize output); $X_{i}$ is a set of independent variables influencing maize output, $\beta_{1}$ and $\beta_{2}$ are the parameters to be estimated, and $\varepsilon_{1 \mathrm{i}}, \varepsilon_{2 \mathrm{i}}$ represent the error terms of the two regression equations. It is assumed that the regression error terms exhibit trivariate normal distribution, mean vector of zero and the following covariance matrix:

$$
\sum=\left\{\begin{array}{ccc}
\sigma_{1}^{2} & \sigma_{12} & \sigma_{1 \mu} \\
\sigma_{12} & \sigma_{2}^{2} & \sigma_{2 \mu} \\
\sigma_{1 \mu} & \sigma_{2 \mu} & \sigma_{\mu}^{2}
\end{array}\right\}
$$

Where $\sigma_{\mu}^{2}$ is a variance of the error term in the first stage (probit) equation. These error terms can be assumed to be equal to 1 because the coefficients are estimable only up to a scale factor. Also, $\sigma_{1}^{2}$ and $\sigma_{2}^{2}$ are variances of the error terms in equations (6) and (7), while $\sigma_{12}, \sigma_{1 \mu}$, and $\sigma_{2 \mu}$ are covariance of $\varepsilon_{1 \mathrm{i}}$ and $\varepsilon_{2 \mathrm{i}} ; \varepsilon_{1 \mathrm{i}}$ and $\mu_{\mathrm{i}}$; as well as $\varepsilon_{2 \mathrm{i}}$ and $\mu_{\mathrm{i}}$.

The residuals (error terms) in equations (6) and (7) are conditional on the Hunger Project credit programme participation (credit access) equation and have non-zero expected value as:

$$
\mathrm{E}\left[\varepsilon_{1 \mathrm{i}} / \mathrm{Z}_{\mathrm{i}}=1\right]=\sigma_{\varepsilon 1 \mu} \frac{\phi(\mathrm{X} \gamma)}{\phi(\mathrm{X} \gamma)}=\sigma_{\varepsilon 1 \mu} \lambda_{1 \mathrm{i}} \text { and } \mathrm{E}\left[\varepsilon_{2 \mathrm{i}} / \mathrm{Z}_{\mathrm{i}}=0\right]=-\sigma_{\varepsilon 2 \mu} \frac{\phi(\mathrm{X} \gamma)}{1-\phi(\mathrm{X} \gamma)}=\sigma_{\varepsilon 2 \mu} \lambda_{2 \mathrm{i}}
$$

Where $\varnothing$ (.) is the standard normal probability density function, $\phi($.$) : the standard normal$ cumulative function. Estimating the productivity equations with ordinary least square (OLS) will lead to bias parameter estimate which is also inconsistent due to endogeneity and selection bias (Maddala, 1983). To obtain unbiased parameter estimate using OLS, Heckman (1979) proposed the inclusion of the inverse mill ratios, which is extracted from the Hunger Project credit programme participation (Credit access) equation (3) into equations (6) and (7).

In the second stage, the inverse mills ratios are calculated as:

$$
\lambda_{1 \mathrm{i}}=\frac{\phi(\mathrm{X} \gamma)}{\phi(\mathrm{X} \gamma)} \text { and } \lambda_{2 \mathrm{i}}=\frac{\emptyset(\mathrm{X} \gamma)}{1-\phi(\mathrm{X} \gamma)}
$$

Equation (10) is based on the probit model at the first stage of estimation, which is added to the explanatory variables of the productivity (outcome) equation as a correction factor.

Concerning the functional form of the productivity equation or model, the study adopted the CobbDouglas production function as used by Freeman et al. (1998). The maximum likelihood method was employed in estimating both the credit supply model and output outcome model following Lokshin and Sajaia (2004). The method is specified as:

$$
\begin{aligned}
& \log l=\sum_{Z=1}\left[\log \left\{\Phi\left(\frac{X \gamma+\left(Y-X \beta_{1}\right) \sigma_{1 \mu / \sigma_{1}^{2}}}{\sqrt{1-\rho_{1 \mu}^{2}}}\right)\right\}-\frac{1}{2}\left\{\log \left(2 \pi \sigma_{1 \mu}\right)-\right.\right. \\
& \left.\left.\left(\frac{Y-X \beta_{1}}{\sigma_{1}}\right)^{2}\right\}\right]+\sum_{Z=0}\left[\log \left\{\Phi\left(\frac{X \gamma+\left(Y-X \beta_{0}\right) \sigma_{2 \mu / \sigma_{2}^{2}}}{\sqrt{1-\rho_{2 \mu}^{2}}}\right)\right\}-\frac{1}{2}\left\{\log \left(2 \pi \sigma_{2 \mu}\right)-\left(\frac{Y-X \beta_{2}}{\sigma_{2}}\right)^{2}\right\}\right]
\end{aligned}
$$

Where $\rho_{1}=\sigma_{1 \mu} / \sigma_{\mu} \sigma_{1}$ is the correlation coefficient between $\varepsilon_{1 i}$ and $\mu_{i}$, and $\rho_{2}=\sigma_{2 \mu} / \sigma_{\mu} \sigma_{2}$ is the correlation coefficient between $\varepsilon_{2 i}$ and $\mu_{i}$. 
Factors influencing farmers participation in the Hunger Project credit programme was identified using the probit model at the first stage of the estimation and inverse mills ratio was extracted from the residuals of the probit model. In the second stage, the productivity equation was estimated with additional regressor "Inverse Mill’s Ratio" (IMR).

The probit model is as specified as.

PARTI(D) $=\beta_{0}+\beta_{1}$ Gen $+\beta_{2}$ Age $+\beta_{3}$ Yrsch $+\beta_{4}$ HHsiz $+\beta_{5}$ Nfi $+\beta_{6}$ Livestok $+\beta_{7}$ Fbo $+\beta_{8}$ Famexpe $+\beta_{9}$ Pyfi $+\beta_{10}$ Fatr $+\beta_{11}$ Fmprp $+\beta_{12}$ Farplp $+\beta_{13}$ Proxepi $+\mu_{\mathrm{i}}$

While the productivity equation of the two groups of farmers is specified as:

$\ln \operatorname{Mprd}_{1 i}=\alpha_{01}+\beta_{1} \ln F_{s i z_{1 i}}+\beta_{2} \ln \mathrm{Herbi}_{1 i}+\beta_{3} \ln \mathrm{Fert}_{1 i}+\beta_{4} \ln S d q t y_{1 i}+\beta_{5} \ln L a b r_{1 i}+\beta_{6} \ln E x t_{1 i}+\lambda_{1 i}+\varepsilon_{1 i}$

if $\mathrm{Z}=1$

and

$\ln \operatorname{Mprd}_{0 i}=\alpha_{02}+\beta_{1} \ln F_{s i z_{0 i}}+\beta_{2} \ln H_{e r b i} i_{0 i}+\beta_{3} \ln$ Fert $_{0 i}+\beta_{4} \ln S d q t y_{0 i}+\beta_{5} \ln L a b r_{0 i}+\beta_{6} \ln E x t_{0 i}+\lambda_{2 i}+\varepsilon_{2 i}$ if $\mathrm{Z}=0$

\subsection{Choice of variables and their description}

In selecting the dependent and independent variables for the models, empirical study by AwunyoVitor and Al-Hassan (2014) on the influence of credit on the productivity of maize in Ghana was used as a guide.

\subsection{Dependent variables}

For the probit model, the dependent variable [PARTI] is assigned " 1 " if the respondent benefited from the Hunger project credit programme and 0 otherwise. In the second stage of the switching regression model, that is the productivity equation, the dependent variable [ $\left.\mathbf{M p r d}_{\boldsymbol{i}}\right]$ is specified as maize output measured in $\mathrm{Kg}$ per hectare of farm size. The total factor productivity measure was adopted for the study.

\subsection{Explanatory variable}

\subsubsection{Gender (Gen)}

Classification of the respondent based on gender is necessary for analysis like this since men and women have different economic activities. Even if they engage in the same activity these might be at a varying scale of operation which may influence their decision to take part in the agricultural programme such as The Hunger Project Credit programme. The gender of the respondent is captured as a dummy variable with a value of 1 representing male respondent and 0 representing female respondents. It is the hypothesis that male respondents are more likely to take part in the programme and have higher productivity than female respondents.

\subsubsection{Age of respondent (Age)}

Is captured as the age of respondent at the time of interview in years. The respondent's decision to participate or not to participate in the Hunger project credit programme may be influenced by how old the respondent is. Given the nature of the credit programme, young farmers are expected to take advantage to expand their scale of operation.

\subsubsection{Years of formal schooling (Yrsch)}

This variable is captured as the number of years the respondent attend a formal educational institution. Farmers who spent more years in attending formal educational institution are likely to have a good idea about credit programmes and farming. According to Musebe et al. (1993), farmers who spent long years in a formal educational institution are more likely to participate in credit 
programmes. It is therefore assumed that increase in the number of years of schooling would positively influence programme participation and productivity of the respondent.

\subsubsection{Household size (HHsiz)}

The variable is specified as the number of individuals who are fed by the respondent. This variable is expected to have a positive effect on the farmer's decision to participate in the Hunger Project credit programme and productivity respectively. Chen and Chivakul (2008) found the family size to be a significant determinant of credit programme participation by individuals in Bosnia and Herzegovina.

\subsubsection{Access to non-farm income (ANfi)}

The respondent who have access to income from other sources, apart from farming activities, are given a value of 1 and otherwise 0 resulting in a dummy variable. According to Bhoj et al. (2013), access to income sources other than farm income negatively affects a farmer's decision to take part in a credit programme. This might be as a result of non-farm income made them more dependent, hence does not need credit to support their activities. However, farmers whose livelihoods are more dependent on farm income are more likely to participate in a credit programme. It is therefore hypothesised that farmer's high non-farm income hurts participation in the credit programme.

\subsubsection{Livestock ownership (Livstock)}

Livestock is considered an asset that can be sold to generate income for the farmer in time of credit constraint. The more livestock the farmer owns, the less likely he/she will participate in a credit programme. Thus, it is assumed that livestock ownership will negatively influence programme participation decision of the farmers in the Hunger Project credit programme. The variable is captured based on tropical livestock unit (TLU).

\subsubsection{Membership of farmer-based organization (Fbo)}

Membership of organisation supports easy access to information and education of programmes. If a respondent belongs to an organisation, 1 represents that respondent and otherwise zero concerning this result in dummy variable. It is assumed that membership of farmer-based organisation will positively influence participation in the Hunger Project credit programme and a positive effect on productivity.

\subsubsection{Experience of the respondent in maize cultivation (Famexpe)}

Agricultural credit programme participation may be heavily influenced by experience. Credit default has its challenges; some farmers have lost their assets due to credit default. Hence, a farmer who has benefited from the previous credit programme will be better inclined to take part in a new credit programme. Also, the more years the farmer has been into maize farming, the more likely it is that he would have to experience agricultural credit. Consequently, the more likely he is to take part in a credit programme. This variable is measured as the number of years the respondent has been into maize cultivation. The variable is therefore hypothesised to have a positive relationship with the respondent's participation in The Hunger Project credit programme.

\subsubsection{Previous year's maize farm income (PYFI)}

The expectation of monetary gain from farming activities also determines programme participation. Monetary gain from farming activities can be assessed based on the previous year's farm income. The farmer is likely to have a low expectation of income if the previous income is low, and may not be willing to make more effort in cultivation by joining a credit programme and vice versa. Therefore, the farmer's decision to join the Hunger Project credit programme will be positively affected by the size of the previous year's income. This may also hurt programme participation in a sense that the farmer may save part of the income to support current year's expenditure, hence may not need additional credit, and may not participate in the credit programme. This variable is a proxy for the wealth of the farmer and captured as total farm income from previous year's maize sales. It 
is hypothesised to have a negative or positive effect on programme participation and productivity respectively, depending on the total value of the income.

\subsubsection{Farmers' attitude towards risk (FATR)}

Smallholder farmers are risk-averse and will not make use of credit when it is available. This is due to the fear of uncertainty associated with crop farming in developing countries due to lack of irrigation facilities. The variable takes the value " 1 " if a farmer's response to series of questions that point to the fact that he/she is risk-averse in respect of participating in credit programme, and " 0 " otherwise. It is hypothesised that this variable would have a negative effect on programme participation and productivity.

\subsubsection{Farmers' perception of loan repayment period (FMPRP)}

This variable indicates how the farmers perceive the period given to them to repay their loan by the Hunger project credit programme. There is a time lag before any agriculture investment becomes apparent. This may affect farmers' decision to participate in the credit programme once they think the repayment period is unrealistic and not convenient. The variable takes a value "1" for respondents who think the repayment period is unrealistic and " 0 " otherwise. The variable is expected to have a negative relationship with the farmer's decision to take part in the Hunger Project Credit programme.

\subsubsection{Farmers' perception of the lending procedure (FARPLP)}

Farmers go through some laid down procedures to get involved with agricultural credit programme to access a loan. The operational modality of these entities may influence the respondent's decision to participate in their credit programme or not. If a respondent perceives the procedure for accessing credit from the programme to be cumbersome this will negatively affect his/her decision to participate in the programme. The variable value " 1 " is assigned if the respondent perceives the participation procedure as cumbersome based on their response to a series of questions, and " 0 " otherwise.

\subsubsection{Proximity to loan centre (Epicentre) (proxepi)}

The distance between the farmer and the loan centre (Epicentre) is expected to influence farmers' decision to take part in a credit programme. Since farmers who live far from the epicentre need to commute a long distance for information and other services, increasing their transaction costs. The variable is assigned " 1 " if the farmer perceives the distance from his/her house to the epicentre to be too far and " 0 " otherwise. It is hypothesised that the more the respondents perceive the distance to be too far the less likely they are to take part in the credit programme.

\subsubsection{Total land under maize cultivation}

[Fsiz $\left.\mathrm{i}_{\mathrm{i}}\right]$ This variable is measured in hectares. It is hypothesised that the variable would have a positive effect on maize productivity. The volume of Herbicides [Herbi ${ }_{i}$ ] used by the respondent is captured in litres. It is assumed that with an increase in the use of herbicide the productivity of maize would increase. Also, the quantity of inorganic fertilizer [ Fert $\left._{i}\right]$ used by the farmer is measured in kilograms $(\mathrm{kg})$. It is hypothesised that increased use of fertilizer would increase maize productivity.

The quantity of seed maize planted $\left[\mathrm{Sdqty}_{i}\right]$ is also expected to influence the productivity of the farmers. This variable is specified as a continuous variable and measured in $\mathrm{kg}$ per hectare. It is a hypothesis that the variable is positively correlated with maize productivity.

\subsubsection{Labour availability and usage}

[ $\left.\mathrm{Labr}_{\mathrm{i}}\right]$ is also expected to influence maize productivity. In this study labour [ $\mathrm{Labr}_{\mathrm{i}}$ ] is specified as the number of workers employed by the farmer to work on the farm for a minimum of 8 hours per 
man-day. It is expected that labour usage will have a positive influence on the maize productivity of the respondent farmers.

\subsubsection{The frequency of extension visits}

$\left[\mathrm{EXT}_{\mathrm{i}}\right]$ by an agricultural extension agent is critical in the adoption of appropriate technology and agronomic and farm management practices, which can influence productivity. The extension $\left[\mathrm{EXT}_{\mathrm{i}}\right]$ variable indicates the number of extension visits per season; it is specified as the number of days agricultural extension agent visit the respondent in a month. Farmers with a higher frequency of visits are more likely to adopt improved technologies, which improves maize output. The frequency of extension visit is hypothesised to positively influence maize productivity.

In the productivity equation, that is, the second stage of the switching regression model, an additional regressor, the Inverse Mill's Ratio (IMR) or Lambda (the residuals produced by the firststage estimate of the probit model) was included as a control variable.

\section{RESULTS AND DISCUSSION}

\subsection{Descriptive statistics of socioeconomic and demographic factors used in the study}

Tables 1, 2 and 3 present the descriptive statistics of the respondents' characteristics and other variables considered in the study. Table 1 shows that male respondents formed $77.9 \%$ of total respondents, while female respondents formed $22.1 \%$. About $84 \%$ of The Hunger Project credit programme participants and $70.6 \%$ of non-participants were male, while $16.5 \%$ of the programme participants and $29.4 \%$ of non-participants were female. This finding indicates that male dominates maize production in the Kwahu West Municipality. The result also showed that $27.6 \%$ of farmers interviewed do not own livestock, while $72.4 \%$ are owners of livestock. About Sixty-eight percent of the credit programme participants and $76.5 \%$ of non- participants own livestock. The results indicate that project non-beneficiaries own livestock more than beneficiaries. The result showed that $49.4 \%$ of the farmers have access to income from off-farm activities, while $50.6 \%$ do not have off-farm income sources. It shows that $29.4 \%$ of participants and $69.4 \%$ of non-participants had access to off-farm income sources. This suggests that non-participants have other income generation sources compared to participants of the programme. This might be the reason why nonparticipants do not participate in The Hunger Project credit programme.

Forty percent $(40 \%)$ of the respondents belong to a farmer-based organisation in the study area, while $60 \%$ do not belong to a farmer-based organization. About group type, $45.1 \%$ of participants and $34.1 \%$ of non-participants belong to farmer-based organizations. The results indicate that most respondents interviewed do not belong to any farmer base organization.

Table 1: Descriptive statistics of socioeconomic and demographic variables (Discrete)

\begin{tabular}{lccccccc}
\hline \multirow{2}{*}{ Variable } & & \multicolumn{2}{c}{ Beneficiaries } & Non-Beneficiaries & \multicolumn{2}{c}{ Pooled } \\
Gender & & Frequency & \% & Frequency & \% & Frequency & \% \\
& Male & 71 & 83.5 & 60 & 70.6 & 131 & 77.9 \\
Livestock owned & Female & 14 & 16.5 & 25 & 29.4 & 39 & 22.1 \\
& No & 27 & 31.8 & 20 & 23.5 & 47 & 27.6 \\
& Yes & 58 & 68.2 & 65 & 76.5 & 123 & 72.4 \\
Off-farm activity & No & 60 & 70.6 & 26 & 30.6 & 86 & 50.6 \\
Membership of & Yes & 25 & 29.4 & 59 & 69.4 & 84 & 49.4 \\
farmer organization & No & 46 & 54.9 & 56 & 56.9 & 102 & 60 \\
\hline
\end{tabular}

Source: Field survey, 2019

The average age of the respondents who took part in the credit programme of the Hunger Project was 49.46 years, while that of non- participants was 59.95 years. The results indicate that most 
respondents are in their middle age; however, those who participated in the credit programme are seemingly younger than non-participants (Table 2). The survey result also shows that the mean household size of programme participants was 7.35 while that of non-participants was 6.88 . From Table 2, the average years of formal schooling for beneficiaries was 6.55 years, while that of nonparticipants was 8.68 years. The result implies that non-beneficiaries had more years of formal schooling than participants of the credit programme.

Table 2: Descriptive statistics of socioeconomic and demographic variables (Continuous)

\begin{tabular}{lcccccccc}
\hline & \multicolumn{4}{c}{ Beneficiaries } & \multicolumn{5}{c}{ Non - Beneficiaries } \\
Variable & Min & Max & Mean & St. Dev & Min & Max & Mean & St. Dev \\
\hline Age & 25.00 & 69.00 & 49.46 & 9.11 & 22.00 & 80.00 & 52.95 & 11.35 \\
$\begin{array}{l}\text { Size of Household } \\
\text { Years of formal }\end{array}$ & 1.00 & 13.00 & 7.35 & 2.79 & 1.00 & 16.00 & 6.88 & 3.02 \\
$\begin{array}{l}\text { education } \\
\begin{array}{l}\text { Livestock } \\
\text { ownership }\end{array}\end{array}$ & 0.00 & 14.00 & 6.55 & 4.86 & 0.00 & 18.00 & 8.68 & 4.36 \\
$\begin{array}{l}\text { Farm experience } \\
\begin{array}{l}\text { Previous year } \\
\text { maize income }\end{array}\end{array}$ & 0.08 & 2.39 & 0.76 & 0.55 & 0.12 & 6.48 & 1.31 & 1.14 \\
\hline
\end{tabular}

Source: Field survey, 2019

On average, respondents owned about 0.76 Tropical Livestock Units (TLU) of livestock, while non-participants owned 1.31 TLU of livestock. This implies that project non-participants owned more livestock than participants. Following Storck et al. (1991) Tropical Livestock Units (TLU) is used to aid comparison of the effect of livestock ownership on maize productivity between participants and non-participants in The Hunger Project credit programme.

Concerning farming experience, farmers who participated in The Hunger Project credit programme had more farming experience than non-beneficiaries. The mean years of experience of participant farmers were 20.87 years, while non-participant farmers had an average of 15.04 years of experience (Table 2). Besides, income from previous year's maize farming activity was assessed. Table 2 indicates that the average income recorded by the participants was GHC208.79. On the contrary, the average farm income for non- participants was GHC355.25. The disparity in farm income may influence farmer participation in the credit programme.

\subsection{Descriptive statistic of farm-level data}

Table 3 presents the descriptive statistics of respondents' farm-level data. The mean maize output of farmers who participated in The Hunger Project credit programme was $1560 \mathrm{~kg}$. This was obtained by using 0.947 -hectare farm size, $17.44 \mathrm{~kg}$ of seed, $194.12 \mathrm{~kg}$ of fertilizer, 4.84 litres of herbicide, 174.61 person-days of labour and 4.54 number of visits by agricultural extension agents. On the other hand, non-participants recorded a mean maize output of $446.47 \mathrm{~kg}$. This was obtained from an average farm size of $0.573 \mathrm{ha}, 8.29 \mathrm{~kg}$ of seed, $100 \mathrm{~kg}$ of inorganic fertilizer, 1.20 litres of herbicide, and 98.60 person-days of labour and 1.60 number of extension visits. The result revealed that beneficiary maize farmers of the credit programme used more of production input and had higher maize output than non-beneficiary maize farmers. 
Table 3: Descriptive statistic of farm-level data

\begin{tabular}{|c|c|c|c|c|c|c|c|c|c|}
\hline \multirow[b]{2}{*}{ Variable } & \multirow[b]{2}{*}{$\begin{array}{l}\text { Variable } \\
\text { Definition } \\
\end{array}$} & \multicolumn{4}{|c|}{ Beneficiaries } & \multicolumn{4}{|c|}{ Non-Beneficiaries } \\
\hline & & Min & $\operatorname{Max}$ & Mean & St.Dev & Min & Max & Mean & St.Dev \\
\hline $\begin{array}{l}\text { Maize } \\
\text { output }\end{array}$ & Maize output in $\mathrm{kg}$ & 500 & 3600 & 1560 & 840.52 & 50 & 1500 & 446.47 & 341.63 \\
\hline Farm size & Farm size in ha & 0.4 & 2.4 & 0.947 & 0.494 & 0.1 & 2.0 & 0.573 & 0.410 \\
\hline Seed & Seed in $\mathrm{kg}$ & 8 & 48 & 17.44 & 9.46 & 2 & 25 & 8.20 & 4.63 \\
\hline Labour & $\begin{array}{l}\text { Labour in person- } \\
\text { days }\end{array}$ & 60 & 462 & 174.61 & 97.85 & 30 & 340 & 98.60 & 69.60 \\
\hline Fertilizer & Fertilizer in $\mathrm{kg}$ & 100 & 500 & 194.12 & 109.49 & 50 & 150 & 100 & 40.83 \\
\hline Herbicide & Herbicide in litres & 2 & 12 & 4.84 & 2.59 & 0 & 6 & 1.20 & 1.595 \\
\hline $\begin{array}{l}\text { Extension } \\
\text { visit }\end{array}$ & $\begin{array}{l}\text { Number of } \\
\text { extension visit per } \\
\text { season }\end{array}$ & 2 & 10 & 4.54 & 1.67 & 0 & 5 & 1.60 & 1.79 \\
\hline
\end{tabular}

Source: Field survey, 2019

The results presented in Table 4 shows that the difference between the productivity of participants and non- participants of The Hunger Project credit programme is positive and statistically significant at the one percent level. Participants produced an average of $1643.5 \mathrm{~kg}$ of maize per hectare $(1.64 \mathrm{mt} / \mathrm{ha})$, while non-participants produced an average of $838.9 \mathrm{~kg}$ of maize per hectare $0.84 \mathrm{mt} / \mathrm{ha}$. This shows that participant farmers achieved higher average maize output per hectare than non-participants. This implies that non-participants can increase their productivity if they had access to credit from the credit programme.

Table 4: Maize productivity level for participants and non-participants in the hunger project programme

\begin{tabular}{lcccc}
\hline Category & Mean & Std.Dev & t-value & 2-Tail sig(P-value) \\
\hline Participants & 1643.5 & 310.6 & 13.09 & 0.000 \\
Non-Participants & 838.9 & 473.9 & & \\
\hline
\end{tabular}

Source: Field survey, 2019

\subsection{Factors influencing farmers' participation in the hunger project credit programme}

The estimated parameters of the probit model on the determinants of farmer's participation decision in the Hunger Project credit programme are presented in Table 5. The model exhibited a 1 percent significant likelihood ratio statistics as indicated by the chi-square statistic. This is an indication that participation has strong explanatory power. In all, eight variables exhibited a significant relationship with farmers' participation decision in The Hunger Project credit programme. These were gender, age, years of formal education, number of livestock owned by the farmer, maize farming experience, previous year's maize income, farmers' perception of lending procedures of The Hunger Project credit programme and farmers' perception of the distance between his/her residence to where the loan is processed and disbursed (epicentre).

The result shows that gender has a positive and significant coefficient, indicating that farmer's participation decision is influenced by their gender. The positive coefficient indicates that male farmers are more likely to participate in the credit programme than female farmers. This is because male farmers cultivate larger farm sizes to their female counterparts. The male farmers thus have high credit needs, which might influence their probability of participation in the programme positively. The male respondents are $25 \%$ more probable to take part in the credit programme compared with female. The result supports the finding of Awunyo-Vitor and Abankwah (2012) which revealed that the probability of male farmers participating in a credit programme is higher 
than that of female farmers. This is because male farmers tend to own larger farm sizes with associated higher demand for finance than their female counterparts.

Age exhibits a negative and significant relationship with the farmer's decision to participate in the Hunger Project credit programme. The result indicates that as farmer advanced in age the lower the probability of him or her participating in a credit programme. This might be because younger farmers are at entry-level in farming and are willing to make more investment compared to older farmers. Alternatively, older farmers may have accumulated some funds over the years from their farming activities, hence do not need funds from such sources to support their farming activities. The marginal effect revealed that additional unit increase in age lowers the probability of the farmer participating in a credit programme by $8 \%$.

The coefficient of years of formal schooling was negative and significant at $1 \%$ level of significance. It shows that maize farmers who are well educated may not take part in such credit programmes. A plausible reason for this is that The Hunger Project's credit programme operates like a semi-formal institution, which might not be attractive to the educated farmers. The result of the marginal effect shows that an additional year of formal schooling education is likely to reduce the probability of the credit programme participation by $2 \%$. The result is consistent with Muhammed (2013), Barslund and Tarp (2008) who found access to formal education to have a negative effect on credit programme participation.

Table 5: Results of the first stage switching regression (probit model) of the factors influencing The Hunger Project Credit Programme participation

\begin{tabular}{lcccc}
\hline Variables & Coefficients & $\begin{array}{c}\text { Standard } \\
\text { Error }\end{array}$ & P-Values & $\begin{array}{c}\text { Marginal } \\
\text { Effect }\end{array}$ \\
\hline Gender & $0.898^{* * *}$ & 0.362 & 2.477 & 0.250 \\
Age of respondent & $-0.045^{* * *}$ & 0.014 & -3.159 & 0.084 \\
Years of formal education & $-0.075^{* *}$ & 0.035 & -2.160 & 0.023 \\
Household size & -0.028 & 0.054 & -0.522 & 0.098 \\
Engagement in off-farm activities & -0.272 & 0.287 & -0.945 & 0.176 \\
Number of livestock owned in TLU & $-0.034 * * *$ & 0.009 & -3.685 & 0.182 \\
Membership in farmer based & 0.375 & 0.270 & 1.387 & 0.201 \\
organizations & $0.060^{* * *}$ & 0.017 & 3.613 & 0.361 \\
Maize farm experience in years & $-.001 * *$ & 0.0005 & -2.200 & 0.281 \\
Previous year's maize income & -0.259 & 0.292 & -0.885 & 0.309 \\
Farmers' perception of risk & -0.022 & 0.359 & -0.062 & 0.231 \\
Farmers' perception of loan repayment & & & & \\
period & & 0.316 & -2.158 & 0.232 \\
Farmers' perception of lending & $-0.682^{* *}$ & & -2.430 & 0.056 \\
procedure & $-0.669 * * *$ & 0.275 & 1.143 & - \\
Farmers' perception of distance & 0.898 & 0.785 & & \\
Constant & & & & \\
No. of observations 170 & & & & \\
LR $\chi^{2}=172.25$ & & & & \\
Prob $>F=0.000$ & & & & \\
Pseudo- $R^{2}=0.289$ & & & & \\
\hline
\end{tabular}

Source: Field Survey, 2019

Note: $* * * * *$ and $*$ indicate statistical significant at $1 \%, 5 \%$ and $10 \%$ level of significance respectively

The coefficient of livestock ownership exhibits a negative relationship with participation, which is significant at $1 \%$ level. This result revealed that if a farmer, owned sufficient livestock he or she is less likely to engage in agricultural credit programme such as The Hunger Project credit 
programme. Livestock is an asset farmer can liquidate during cropping season to purchase inputs, thereby reducing their need for credit. Livestock ownership, therefore, tends to reduce the probability of farmers participating in the credit programme by $18 \%$.

The coefficient of maize cultivating experience variable is positive and statistically significant at $1 \%$ level. Over time, farmers may gain experience which might influence their confidence that if they take a loan they would be able to pay back, hence higher tendency to participate in the credit programme. Therefore, an additional year of experience has about $36 \%$ chance of inducing farmers to take part in a credit programme. The result is consistent with findings of Ambali (2013) who argued that farming experience has a positive effect on credit programme participation.

The coefficient of the previous year's income from maize sales is negative and significant at 5\% level. This variable has a marginal effect of 0.28021 , which implies that when income from maize sales increase by one unit, the probability of credit programme participation would reduce by $28 \%$. This is rational because, with high income, the farmer is not constrained in the purchase of inputs for his/her farming activity and will not participate in a credit programme. This result is consistent with the finding of Awunyo-Vitor et al. (2014) which revealed that an increase in farmer's income would reduce farmers need for credit market participation.

The coefficient of the variable representing farmers' perception of the lending procedure exhibits a negative and significant relationship with participation. The estimate is statistically significant at $1 \%$ level with a marginal effect of 0.23245 . The unrealistic lending procedure is likely to reduce the probability of credit market participation by $23 \%$. Cumbersome loan procedure serves as a disincentive for participating in a credit programme as observed by Awunyo-Vitor et al. (2014) and Chauke et al. (2013) in Ghana and Nigeria respectively.

The coefficient of the variable farmers' perception of the distance between his/her house and the epicentre (loan centre) had a negative and significant relationship with participation in the credit programme. The coefficient is statistically significant at $1 \%$ level with a marginal effect of 0.0567 . The result indicates that respondents that think the distance between their house and the epicentre is far are about $6 \%$ less likely to participate in the credit programme. This result might be that farmers who are far away from the epicentre may incur higher transaction cost in participating in the programme which may serve as a disincentive them. The result is consistent with Chauke et al. (2013) and Hussien (2007) who acknowledged that farm households are discouraged to participate in credit market when the loan sources are situated further away from their residence.

\subsection{Impact of the hunger project credit on maize productivity}

Table 6 presents the result of the impact of maize farmers' access to The Hunger Project credit on their productivity. The coefficient of fertilizer had a positive sign for both beneficiary and nonbeneficiary farmers and statistically significant at 5\% level for participants and $1 \%$ level for nonparticipants in the credit programme. This implies that a unit increase in fertilizer use will lead to about $17.21 \%$ increase in maize output for the participant and $17.93 \%$ for non- participants respectively. The implication is that fertilizer use increases maize output for both groups of farmers. The result confirms the findings of Okoboi et al. (2012) and Obasi et. al. (2013) who concluded that fertilizer increases the productivity of land, which leads to increase output.

The coefficient of labour exhibited a positive sign and statistically significant at the $5 \%$ level for farmers who participated in credit programme and insignificant for non-participants. An additional unit of labour would lead to $17.72 \%$ increase in maize output of this group of farmers. This suggests that labour increase support maize output of only participants. This might be because it is only participants who have enough funds to purchase the required inputs to support the productivity of labour. This result is consistent with the findings of Nuryartono et al. (2005). 
Table 6: Results of the second-stage switching regression model of maize Productivity

\begin{tabular}{lcc}
\hline Variable & $\begin{array}{c}\text { Participants } \\
\text { Coefficient (Standard Error) }\end{array}$ & $\begin{array}{c}\text { Non- participants } \\
\text { Coefficient (Standard Error) }\end{array}$ \\
\hline Fertilizer & $0.172^{* *}$ & $0.179^{* * *}$ \\
& $(0.083)$ & $(0.068)$ \\
Labour & $0.177^{* *}$ & 0.432 \\
& $(0.086)$ & $(0.279)$ \\
Extension visit & 0.005 & 0.052 \\
& $(0.011)$ & $(0.038)$ \\
Quantity of seed & $0.048^{*}$ & $0.708^{* * *}$ \\
& $(0.151)$ & $(0.291)$ \\
Herbicide & $-0.113^{* *}$ & $0.188^{*}$ \\
& $(0.055)$ & $(0.108)$ \\
Farm size & $0.742^{* * *}$ & -1.057 \\
Constant & $(0.141)$ & $(0.308)$ \\
& $5.592^{* * *}$ & 2.278 \\
Inverse mill ratio & $(0.590)$ & $(1.492)$ \\
& $-1.750^{* * *}$ & $-0.553^{* * *}$ \\
$\rho_{1}$, & $(0.082)$ & $(0.078)$ \\
$\rho_{2}$ & $0.504^{*}$ & - \\
No. of observations 170 & $(0.300)$ & 0.156 \\
LR $\chi^{2}=172.25$ & - & $(0.414)$ \\
Prob $>F=0.00$ & & \\
Pseudo- $R^{2}=0.289$ & & \\
\hline
\end{tabular}

Source: Field Survey, 2019

Note: $* * *, * *$ and $*$ indicate statistical significant at $1 \%, 5 \%$ and $10 \%$ level of significance respectively

Seed variable exhibited positive coefficient which is statistically significant at $5 \%$ and $1 \%$ level for beneficiaries and non-beneficiaries respectively. The results suggest that the use of seed had a significant effect on maize output per hectare for the two groups of farmers. A unit increase in seed usage leads to $4.85 \%$ and $70.79 \%$ increase in maize output for farmers who accessed credit from the programme and those who did not access credit from the programme respectively.

The coefficient of the variable herbicide exhibits a negative and statistically significant at $5 \%$ level for participant farmers. The results revealed that a unit increase in herbicide use leads to $11.36 \%$ decrease in maize output of participant, which may be attributed to overutilization of the input. The result is consistent with Oluwatayo et al. (2008) who found a negative relationship between agrochemical use and farm output. However, the herbicide has a positive sign and statistically significant at $10 \%$ level for non-participants. Thus, a unit increase in herbicide use leads to an $18.81 \%$ increase in maize output of non-participants.

The coefficient of farm size has a positive sign and statistically significant at $1 \%$ level for participant farmers. This implies that farm size significantly influences the maize output of participant farmers. Generally, a hectare increase in farm size of participants would lead to $74.28 \%$ increase in maize output per hectare. The result is consistent with the findings of Obasi et al. (2013) which reveal that farm size has a significant effect on productivity.

The coefficient of the inverse mills ratio which shows the correlation between the credit market participation (probit model) and the productivity equation (productivity equation) of participants 
$\left(\rho_{1}\right)$ is positive and statistically significant at the $10 \%$ level. However, the coefficient of the inverse mills ratio for non-participants $\left(\rho_{2}\right)$ is not statistically significant. The results imply that the models cannot be estimated separately. The result of the study is consistent with Boucher and Guirkinger (2007), Feder et al. (1990), Awunyo-Vitor et al. (2014) and Dong et al. (2012).

\subsection{Conclusion and recommendations}

The Hunger Project credit programme was initiated to provide solutions to the low productivity of maize farmers. The underlying aim was to reduce hunger and poverty by enhancing the productivity of smallholder farmers. The study provides insight into how agricultural credit programme could impact the productivity of smallholder maize farmers, using a two-stage switching regression model. The result of the first stage probit model revealed that gender, age, formal education, livestock ownership farming experience, income from previous year's maize harvester, farmer's perception of the lending procedure and income are the factors that significantly influence participation in the Hunger Project credit programme.

The productivity results revealed that all the inputs employed by the project beneficiaries had a significant effect on maize productivity, except the number of extension visit per month. The result further shows that maize farmers who had access to credit had higher productivity, while those who did not benefit from the Hunger Project credit programme had lower productivity. The productivity differences between the beneficiaries and non-beneficiaries of the Hunger Project Credit programme revealed that non-beneficiary farmers could increase their productivity substantially if they have access to credit. It is therefore concluded that the Hunger Project credit programme has a positive impact on maize productivity in the Kwahu West Municipality. Besides, access to credit by farmers in the area would positively upscale maize productivity.

It is therefore recommended that the Hunger project credit programme or similar credit project should design policies to encourage patronage of the programme to ensure more non-participants to join the programme to increase maize output per hectare. It is believed that an increase in access to credit would increase farmer's access to purchased farm input to increase their productivity. Also, efforts should be made by the Department of Agriculture at the District Assembly to improve extension education and more staff should be engaged to increase the frequency of visit to the farmers within the Kwahu West Municipality. This would consequently improve farmer's income and their livelihood in the study area. This recommendation is worth considering as it is clear that the anticipated productivity gain is high to discourage farmers who will benefit from the credit programme from investing it elsewhere for higher marginal productivity gain.

Funding: This study did not receive any specific financial support.

Competing Interests: The authors declared that they have no conflict of interests.

Contributors/Acknowledgement: All authors participated equally in designing and estimation of current research.

Views and opinions expressed in this study are the views and opinions of the authors, Asian Journal of Agriculture and Rural Development shall not be responsible or answerable for any loss, damage or liability, etc. caused in relation to/arising out of the use of the content.

\section{References}

Adegeye, A. J., \& Dittoh J. S. (1985). Essential of agricultural economics. Ibadan: Impact Publishers Nigeria, Ltd.

Ajayi, A. R. (2005). Programme planning, monitoring and evaluation in agricultural extension. Agricultural Extension in Nigeria. Ilorin: AESON, ARMTI, 38-59.

Alam, A., Kobayashi, H., Matsumura, 1., \& Siddighi, B. B. (2012). Factors influencing farmers participation in participatory irrigation management: comparative study of two irrigation schemes in northern area of Pakistan. Mediterranean Journal of Social Science, 3(9), 271280. 
Ambali, O. I. (2013). Microcredit and technical efficiency of rural farm households in Egba division of Ogun state Nigeria. Journal of Agriculture and Sustainability, 2(2), 196-211.

Andam, K., Al-Hassan, R., Asante, S., \& Diao, X. (2015). Is Ghana making progress in Agroprocessing? Evidence from an inventory of processed food products in Retail shops in Accra. Ghana strategy support program working paper, 41. Accra: International Food Policy Research Institute, Ghana.

Andam, K., Johnson, M., Ragasa, C., Kufoalor, D., \& Gupta, S. (2017). A chicken and maize situation: the Poultry feed Sector in Ghana. IFPRI Discussion Paper, 01601. Washington, DC: USA.

Aref, F. (2010). Barriers to community capacity building fortourism development in communities in Shiraz, Iran. Journal of Sustainable Tourism, 6(2), 136-142. doi.org/10.1080/09669582.2010.517314.

Armah, M. (2009). Maize, soya and rice production and processing. Millennium Development Authority. Ghana.

Asante-Addo, C., Mockshell, J., Zeller, M., Siddig, K., \& Egyir, I. S. (2017). Agricultural credit provision: What really determines farmers' participation and credit rationing?, Agricultural Finance Review, 77(2), 239-256. doi.org/10.1108/afr-02-2016-0010.

Awunyo-Vitor, D., \& Al-Hassan, R. M. (2014). Credit constraints and smallholder maize production in Ghana. International Journal of Agricultural Resources, Governance and Ecology, 10(3), 239-256. doi.org/10.1504/ijarge.2014.064007.

Awunyo-Vitor, D., \& Abankwah, V. (2012). Substitutes or complements? formal and informal credit demand by maize farmers in Ashanti and Brong Ahafo regions of Ghana. International Journal of Agriculture and Forestry, 2(3), 105-112. doi.org/10.5923/j.ijaf.20120203.05.

Awunyo-Vitor, D., Al-Hassan, R. M., \& Sarpong, D. B. (2014). Impact of formal financial market participation on farm size and expenditure on variable farm inputs: the case of maize farmers in Ghana. ISRN Economics, 2014. doi.org/10.1155/2014/329674.

Awunyo-Vitor, D., Wongnaa, C.A. \& Aidoo, R. (2016). Resource use efficiency among maize farmers in Ghana. Agriculture \& Food Security, 5(1), 28. doi.org/ DOI 10.1186/s40066016-0076-2.

Barslund, M., \& Tarp, F. (2008). Formal and informal rural credit in four provinces of Vietnam. Journal of Development Studies, 44(4), 485-503.

Bartlett, J., Kotrlik, I. J. W., \& Higgins, C. C. (2001). 'Organisational research: determining the appropriate sampling size in survey research'. Information Technology, Learning and Performance Journal, 19(1), 43-50.

Benin, S., Johnson, M., Abokyi, E., Ahorbo, G., Jimah, K., Nasser, G., Owusu, V., Taabazuing, J., \& Tenga, A. (2013). Revisiting agricultural input and farm support subsidies in Africa; the case of Ghana's mechanization, fertilizer, block farms, and marketing programs: International Food Policy Research Institute, Washington, D.C., USA.

Bhoj, S., Bardhan D., \& Kumar, A. (2013). Determinants and implications of rural women's participation in microfinance programme: an analysis of dairy self-help groups in Uttarakhand State of India: Department of Veterinary and AH Extension Education. College of Veterinary and Animal Sciences G.B. Pant University of Agriculture and Technology, Pantnagar - 263 145, Uttarakhand, India: Livestock Research for Rural Development 25 (10) Cambridge, U.K.: Cambridge University Press.

Botlhoko, G. J., \& Oladele, O. I. (2013). Factors affecting farmers participation in agricultural Projects in Ngaka Modiri Molema district north west province, South Africa: Journal of Human Ecology, 41(3), 201-206.

Boucher, S., \& Guirkinger, C. (2007). Credit constrain and productivity in Peruvian Agriculture. Working paper No.07-005, Department of Agriculture and Resource Economics, University of Califonia, Davis, USA. 
Butler, W. A., \& Cornaggia, J. (2011). Does access to external finance improve productivity? evidence from a natural experiment. Journal of Financial Economics, 99(1), 184-203. doi.org/10.2139/ssrn.1084154.

Chauke, P. K., Motlhatlhana, M. L., Pfumayaramba, T. K., \& Anim, F. D. K. (2013). Factors influencing access to credit: a case study of smallholder farmers in the Capricorn district of South Africa. African Journal of Agricultural Research, 8(7), 582-585.

Chen, C. K., \& Chivakul, M. (2008). What drives household borrowing and credit constrains? Evidence from Bosnia and Herzegozna. Economics, 19, 33-44.

Ciaian, P., Fałkowski, J., Kancs, D., \& Pokrivcak. J. (2011). Productivity and credit constraints firm-level evidence from propensity score matching. Working papers 117484, Factor Markets, Centre for European Policy Studies, Brussels, Belgium.

Cole, S. (2006). Information and empowerment: the keys to achieving sustainable Tourism. Journal of Sustainable Tourism, 14(6), 629-644.

Dong, F., Lu, J., \& Featherstone, A. M. (2012). Effects of credit constraints on productivity and rural household income in China. Agricultural Finance Review, 72(3), 402-415.

Edgerton, M. D. (2009). Increasing food productivity to meet global needs for food, feed and fuel. Plant Physiology, 149, 7-13.

Feder, G., Lau, L., Lin, J., \& Luo, X. (1990). The relationship between credit and productivity in Chinese agriculture: a microeconomic model of disequilibrium. American Journal of Agricultural Economics, 72(5), 1151-1157. doi.org/10.2307/1242524.

Freeman, H. A., Ehui, S. K., \& Jabbar, M. A. (1998). Credit constraints and smallholder dairy production in the east African highlands: Application of a switching regression model. Agricultural Economics, 19, 33-44. doi.org/10.1111/j.1574-0862.1998.tb00512.x.

Ganesh, P. S., \& Surendra, B. T. (2005). Farmers' perception of participation and institutional effectiveness in the management of mid-hill watershed in Nepal. Environment and Development Economics, 10(5), 665-687. doi.org/10.1017/s1355770x0500238x.

Ghana Living Standard Survey Round 7 (GLSS7) (2018). Poverty trends in Ghana, 2005-2017. Ghana Statistical Service, Accra, Ghana.

Ghimir, N, R., Petheram, J. R., \& Perkins, M. J. (2009). Participatory agricultural development in Nepal: Discrepancies between Policies. Views and Experiences: Proceedings of the $25^{\text {th }}$ Annual Meeting, InterContinental San Juan Resort, Puerto Rico.

Gujarati, D. N. (2004). Basic Econometrics. $4^{\text {th }}$ Edition. McGraw-Hill Book Company. New York, USA.

Heckman, J. (1979). Sample selection as a specification error. Econometrica, 47, 153-161.

Hurelbrink, R., \& Boohene, G. (2011). Ghana feed sector assessment report. Report for ACDI/VOCA, Ghana.

Hussien, H. (2007). Farm household economic behaviour in imperfect financial markets. Doctoral Thesis, Swedish University of Agricultural Sciences, Uppsala, Sweden.

Kwahu West Municipal Assembly (2014). Medium Term Development Plan 2014-2017. Government of Ghana, Ghana.

Lokshin, M., \& Sajaia, Z. (2004). Maximum likelihood estimation of endogenous switching regression models. The Stata Journal, 4(3), 282-289. doi.org/10.1177/1536867x0400400306.

Long, J. S. (1997). Binary outcomes: the linear probability, probit and logit models. from Long J. Scott, Regression models for categorical and limited dependent variables, pp 33-84, Thousand Oaks: Sage Publications, India.

Maddala, G. S. (1983). Limited dependent and qualitative variables in economics. New York: Cambridge University Press, 257-291. USA.

MOFA (2011). Agriculture in Ghana. Facts and Figures (2010) Statistics. Research and Information Division (SRID), Ministry of Food and Agriculture, Government of Ghana, Accra, Ghana.

Muhammed, M. A. (2013). Formal and informal credit demand by rice farmers in the Northern Region of Ghana. Thesis, Master of Philosophy in Economics. University of Ghana, Ghana 
Mundlak, Y. (1992). Agricultural productivity and economic policies: Concepts and measurements. OECD Working Paper No. 75, OECD Development Center.

Musebe. R., Oluoch, W., Kosura,R., \& Wangia, C. (1993). An analysis of agricultural credit market Invihiga division of Kaka Mega district, Kenya, East Africa. Agriculture and Forestry Journal, 58(3), 117-126. doi.org/10.1080/00128325.1993.11663166.

Muturi, W., \& Nzomo M. (2014). The effect of types of agricultural credit programmes on productivity of small scale farming businesses in Kenya: A survey of Kimilili Bungoma Sub County. Journal of Economics and Sustainable Development, 5(23), 1-12.

Nagler, J. (1994). Interpreting probit analysis. New York University. Retrieved from http://www.nyu/classes.

Nuryartono, N., Zeller, M., \& Schwareze, S. (2005). Credit rationing of farm households and agricultural production: empirical evidence in rural areas of central Sulawesi, Indonesia. Paper presented at the conference on International Agricultural Research for Development, 11-13 October. Stuttgart-Hohenheeim, Germany.

Nxumalo, K. K. S., \& Oladele, O. I. (2013). Factors affecting farmers' participation in an agricultural programme in Zululand District, Kwazulu Natal Province, South Africa. Journal of Social Science, 34(1), 83-88.

Obasi, P, C., Ukoha, A. H., Ukewuihe, I. S., \& Chidiebere, N. M. (2013). Factors Affecting Agricultural Productivity Among Arable Crop Farmers in Imo State, Nigeria. American Journal of Experimental Agriculture, 3(2), 443-454.

Okoboi, G., Muwanga J., \& Tumwabze T. (2012). Use of improved inputs and its effect on maize yield and profit in Uganda. African Journal of Food, Agriculture, Nutrition and Development, 12(7), 1-8.

Oladele, O. I. (2012). Socio economic determinants of use of indigenous fallow system for enhancing soil fertility among farmers in oyo state of Nigeria. Life Science Journal, 9(3), 2424-2428.

Oluwatayo, I. B., Sekumade, A. B., \& Adesoji, A. S. (2008). Resource use efficiency of maize farmers in rural Nigeria: evidence from Ekiti State. World Journal of Agriculture Sciences 4(1), 91-99.

Ozowa, V. N. (2007). Information needs of small-scale farmers in Africa: the Nigerian example. Available at: http://www.worldbank.org/html/cgiar/newsletter/june97/9nigeria.html.

Ragasa, C., Dankyi, A., Acheampong, P., Wiredu, N, A., Chapoto, A., Asamoah, M., \& Tripp, R. (2013). Patterns of adoption of improved maize technologies in Ghana. GSSP Working Paper 34. Accra: IFPRI, Ghana.

Shete, M., \& Garcia, R. J. (2011). Agricultural credit market participation in Finoteselam towm, Ethiopia, Journal of Agribusiness in Developing and Emerging Economies, 1(1), 55-74.

Sithole, N. L., Lagat, J. K., \& Masuku, B. M. (2014). Factors influencing farmers participation in smallholder irrigation schemes: the case of Ntfonjeni rural development area. Journal of Economics and Sustainable Development, 5(22), 1-23.

Storck, H., Bezabih, E., Berhanu, A., Borowiccki, A., \& Shimelis W. H. (1991). Farming System and Farm Management Practices of Smallholders in the Hararghe Highland. Farming Systems and Resource Economics in the Tropics, 11, Wissenschaftsverlag Vauk, Kiel, Germany.

Telayneh, G. (2010). Major factors influencing farmers' participation in skill training program in assosa zone. Retrieved from www.acadamia.edu.htm.

The Hunger Project-Ghana (2013). Starter Plugs to end hunger and poverty among women and men in rural Ghana. Annual report, Ghana.

Yehuala, S. (2008). Determinants of smallholder farmers access to formal credit. A case of Metema Woreda, North Gonder, Ethiopia. Unpublished Master's Thesis. Haramaya University, Ethiopia. 